\title{
Editing and the Shadow of the Folio: \\ On the Textual Integrity of The Taming of a Shrew (1594)
}

\section{Roy Eriksen}

Many critics hold the opinion that The Taming of the Shrew, published for the first time in the 1623 Folio, must have preceded the shorter The Taming of a Shrew, published in "good" quartos in 1594, 1596 and 1607, due to doubt whether anyone but Shakespeare could have constructed such an intricate plot. As I will argue in this article, such precedence exists in the deftly planned and integrated plot structure in Marlowe's Doctor Faustus (1587-89), a play intimately connected to A Shrew in terms of style and verbal loans.

When Martin Wiggins, in Drama and the Transfer of Power in Renaissance England, engages with the problem of various types of public spectacle that have not survived as texts, he underlines that the type of spectacle he focuses on (masques, processions, etc.) was in the final analysis "designed for performance, and not as a purely literary artifact," rightly placing his emphasis on drama's "other components: props and costumes, music and sound effects, the bodies and voices of actors in motion." ${ }^{2} \mathrm{He}$ can thus concentrate on the specificity of his particular objects of investigation. This exactly reverses the situation of stage drama where what survives is mainly printed texts. Contrary to what some contemporary directors, actors and critics would like to believe, a Renaissance

Early Modern Culture Online vol. 6 (2015) 49-68.

ISSN: 1892-0888 www.uia/emco
Lord. My Lord this is but the play, they're but in jest. ${ }^{1}$

play was, before it was rehearsed and performed, a textual construct or literary composition designed with the specific aim to entertain and instruct when enacted. It was definitely not the result of a majority vote between dramatist, actors, and stage workers during rehearsal. Of course, early modern plays did change in performance, perhaps because things did not go home with the audience or were palatable to the authorities, and some such changes survive in bad quartos and pirated texts printed post-performance. Not least a play did change when it was revived with new materials added, or had passed from one company to another. Plays were shortened to allow smaller companies to tour the provinces in times of plague $^{3}$ and later were faced with the duopoly that the Lord Chamberlain's Men and the Admiral's Men set up in 1594. ${ }^{4}$ Despite such changes texts survived in printed versions that provide records of what had happened to them when subjected to commercial, political or social pressures.

The situation in London around 1590 was very different indeed, from that of contemporary theatre when modern directors in quest of novelty and relevance cut scenes or import entirely new materials into a play in deference to contemporary taste, directors frequently create performances that diverge 
notably from, and that only tangentially resemble, the received text and its formal intention. This is particularly evident in the way plays have been made to conclude differently. Thus we have received a happy ending King Lear and a feminist The Taming of the Shrew. Famously in the $17^{\text {th }}$ century the poet laureate, Nahum Tate, in 1681 supplied King Lear with an ending in which Cordelia survives to marry Edgar, and some 50 years ago Trevor Nunn altered the stage history of The Shrew, when he imported Sly's final appearance in A Shrew to give completion to The Shrew. ${ }^{5}$ Since the 1970 s we have witnessed several such political adjustments to The Shrew, coupled with an extensive use of doubling. ${ }^{6}$ The result is a challenging feminist and politically correct Shrew that restores somewhat the image of Shakespeare as a "humane" dramatist, although one tends to forget that The Shrew is not alone among his plays to show a less humane playwright. ${ }^{7}$ The result of the situation is that we are faced with many versions of The Taming of the Shrew, a texte combinatoire. Barbara Hodgdon writes:

Folio The Shrew, The Shrew without Sly, The Shrew with A Shrew's Sly ending, The Shrew with most (or all) of the Sly materials, The Shrew with the Sly materials and a rescripted 'Induction' (Alexander, 1992) and The Shrew with directorially or collaboratively written frames (Marowitz, 1973; Bogdanov, 1978). ${ }^{8}$

The situation seems to be one of free for all.
Editing has always been a complex and controversial business, becoming even more so in the age of the world of digitalized media and on-line editions. At the same time, contemporary editors also tend to spend much space on provoking and innovatory changes in performances, ${ }^{9}$ thus exerting pressure on the play-text as received with the inevitable result of establishing new traditions that break with the traditional editorial practices that essentially are aimed at a diminishing band of textual scholars; practices that are felt to be irrelevant to the vast majority of readers and theatre-goers. But such novelty may also come at a cost. Many were surprised when the RSC production of The Merchant of Venice a few years ago featured an imitation of Elvis Presley performing the song "Viva Las Vegas." It was a striking and entertaining performance, aligning Venice with Las Vegas, but the show act did in fact torpedo much of the impact of the rest of the play. For how much can a director alter a play, or introduce bits of another play, and still use the same title? Licentia poetica or spectaculi in such cases risks creating a new work in a new mode, and even genre, that disrupts what is prepared for and embedded in the work, what I elsewhere have termed its "formal intention."10

For instance, the insertion of the final Sly scene from A Shrew into the conclusion of The Shrew disrupts that intention and creates a "different sense of an ending," as it were, in the text first printed in the Folio, at the same time disregarding both the literary and dramatic specificity of $A$ Shrew, where Sly remains on stage throughout. That specificity and its relation to the formal intention embedded in 
text printed in 1594 is what I wish to explore in this article.

Regardless of whether The Shrew is considered the source of $A$ Shrew, a revision of The Shrew, or A Shrew is a memorial reconstruction of The Shrew, a lot can be learned from examining it as an independent play that belongs to a literary and theatrical context from which several of Shakespeare's plays evolved. In their old-spelling edition of the play (1992), ${ }^{11}$ Graham Holderness and Bryan Loughrey did just that presenting a thought-provoking approach to the problematic relationship between A Shrew and Shakespeare's comedy. They focus on metadrama and genre in relation to "Shakespeare," what I would term "the collective memory of dramatic forms existing at the time [a] play was written"12 and argue that $A$ Shrew is a play in its own right. Michael Roy Miller in his modernspelling edition of $A$ Shrew (1998) does not engage with the challenge posed by Holderness and Loughery's edition to the current orthodoxy, but somewhat contradictory finds the play both independent and "derivative."13 For what kind of comedy is The Taming of a Shrew, and how carefully is it crafted? Is it merely the work of a "compiler" and a "plagiarist" or does it present an independent and even sophisticated take on the much discussed taming of Kate?

The concept of a "formal intention" necessarily implies a considerable degree of design and consistency in a text. Most critics of the play admit that there is some such consistency, especially the Sly material is more complete in $A$ Shrew, a fact pointed out by Leo Salingar already in 1972, when he observed that
A Shrew has a puzzling relation to The Shrew, because Sly remains attentive and draws moral at the end from what he has seen. Many editors believe that Shakespeare's text must have continued with a like scene at the end. But rather than being a dunce, in $A$ Shrew Sly knows what a comedy is and it is the Players who blunder, whereas in Shakespeare (himself an Actor) the point seems precisely that his actors are wasted on spectators like Sly. ${ }^{14}$

This inevitably identifies the playwright as one who can handle several plots simultaneously. ${ }^{15}$ The majority of editors and critics have tried to overcome this awkward fact either by arguing that there is no need for Sly after Kate has changed personality, or by seeing the more integrated ending of $A$ Shrew as belonging to a lost version of Shakespeare's play or a lost source play behind the anonymous 1594 "bad" quarto. Ann Thompson comments as follows upon the "good" quality of the 1594 Quarto:

The combination of the three plots is a remarkably sophisticated example of dramatic structure for the early 1590s and the detailed execution of parts of the play is also very impressive. ${ }^{16}$

This fact seems to be disturbing to critics and editors who claim that Shakespeare alone could manage such finesse around 1590, so Shakespeare's play, too, originally must have had such a concluding scene with Sly and that it therefore must be the earlier play. ${ }^{17}$ Hodgdon, in her refreshingly unbiased discussion of dating, 
concludes that "the play we identify as The Shrew post-dates A Shrew and came into being after 1594, [and] it seems neither responsible nor possible, lacking further evidence, to determine a more decisive date for The Shrew."18 The claim otherwise would entail continuing acceptance of Shakespeare's preeminence in everything. That effect is what I refer to as the shadow of the Folio, that makes an incomplete play printed 29 years later than the editio princeps of The Taming of a Shrew (1594) the earlier text. Richard Hoseley is among those who believe the shorter and earlier play to be an imitation of Shakespeare's play. He therefore concludes that

[i]t is doubtful whether by 1594 any English dramatist other that Shakespeare was sufficiently skilled in plot-construction to write a carefully and subtly integrated tripleaction play as we should have to suppose a lost original to be if $A$ Shrew were derived from it in the manner envisaged by modern textual theory."19

Here complexity of construction seems to be a skill only attributable to Shakespeare. On the other hand, Miller in his edition of the 1594 Quarto fully recognizes that it possesses an element of completeness, principally seen in the meta-theatrical framing device involving Sly and the fully developed Aurelius plot. ${ }^{20}$ He rather fancifully suggests that an "adapter" may have acted as a "play doctor" and improved "The Shrew- while cutting it-stuffing it with the sort of material currently in demand in popular romantic comedies" (10), ${ }^{21}$ and of course adding a coating of Marlowe's "mighty lines". Still, he also believes "that $A$ Shrew is derivative and that The Shrew is the original piece," and thus what is structured and complex is by implication owed to Shakespeare. He does however hasten to add that "we benefit greatly from accepting $A$ Shrew as a viable comic text of its period." 22 Miller neither, then, has a good answer to "why, when A Shrew contains so much in common with The Shrew, does it have such a large amount of material that is different? ${ }^{23}$

In fact, to have "in common" in the sense of being similar is not the same as sharing the same lines, for as Kathleen O. Irace points out in Reforming the 'Bad' Quartos: Performance and Provenance in Six Shakespearean First Editions, ${ }^{24}$ less than one percent of the lines in A Shrew closely parallels those of The Shrew. This strongly suggests that $A$ Shrew is not an imitation or version of The Shrew, ${ }^{25}$ but a play in its own right, possessing structural and stylistic qualities of its own. ${ }^{26}$ What she, Miller and Hoseley before him do not seriously consider, however, is the undeniable fact that there was at least one other writer at hand who was capable of handling several plots, and that plays containing evidence of this skill invite examination. The obvious name is Christopher Marlowe, whose early plays are so frequently echoed in A Shrew to the extent that it has been labeled "Marlovian." 27 The "Marlovian" elements consist of whole lines or short passages from plays such as Tamburlaine and Doctor Faustus, vocabulary typical of Marlowe, and obvious examples of his compositional practices, temperament, and style. ${ }^{28}$ 
Let me discuss two ways in which A Shrew emerges an independently conceived and complete text, examples that emerge when the specificity of the text is addressed and not filtered through what goes on in the Folio play. I will focus briefly on a) the formal intention embedded in the configuration of the play's scenes and settings, and b) the author's use of periodicity in speech construction, with special attention to Kate's final speech. First, just how does formal intention manifest itself? Ben Jonson's frequently quoted lines in Timber, or, Discoveries indicate how this may be seen at the basic level of dispositio:

As, for example, if a man would build a house, he would first appoint a place to build it in, which he would define within certain bounds, so, in the constitution of a poem, the action is aimed at by the poet, which answers place in a building, and that action hath his largeness, compass, and proportion. So the epic asks a magnitude, rom other poems: since, what is place in the one is action in the other, the difference is in space. ${ }^{29}$

The lines point to a principle of abstract planning and an intended effect (cf. "aimed at by the poet") that would appear if the poem's textual places, or spaces, were subjected to systematic mapping, e.g. as outlined by William Scott in The Model of Poesy (1599), who draws extensively on architectural terminology. ${ }^{30}$ In a play such a series of actions - the plot - can be abstracted and represented as a drawing or figure projected unto a flat surface. We are all acquainted with such systemic analytical procedures, that are used to map linguistic and stylistic registers, rhyme-schemes and versification, but we are less familiar perhaps with those that fall under the category of topomorphology, which is "a type of rhetorical analysis which entails studying the distribution and design of topoi, or segments devoted to specific topoi, within the structured body of the text (morphê)." 31 In other words in literature, topomorphology considers the spatial relationships and configurations formed by thematically defined and rhetorically patterned segments within a text, while in the arts it considers for example the integration and execution of parts on a pictorial plane or within an edifice or building plan. This is an approach similar to Elizabethan practice, according to which "classroom analysis of a poem demanded of the student that he clarify the precise interrelationship of its parts."32

Marlowe's Doctor Faustus is a case in point, a successful play written by a university wit, and echoed throughout $A$ Shrew. It is extant in two versions published well after the dramatist's death, one in 1604, the short so-called A text, and a second longer one published in 1616, the so-called B-text. ${ }^{33}$ Both are to a varying degree and according to critical opinion versions of a play that was acted on the London stage prior to 1590, when Shakespeare saw and later echoed it as in the final scene of King John. Marlowe's play, then, was probably composed between late 1587 and 1589. ${ }^{34}$ This date places it very close to the composition of Tamburlaine, Parts One and Two, other plays that are echoed in A Shrew. The two versions of Marlowe's tragedy lend themselves to an investigation that does not depend on taste 


\section{Figure 1}

$\left.\begin{array}{ccccc}\text { Wittenberg papal court } & \text { Wittenberg imperial court } & \text { Wittenberg ducal court } & \text { Wittenberg } \\ {[1-7]} & {[8-9]} & {[10]} & {[11-14]} & {[15]}\end{array}\right]$

and fineness of ear, but on measurable and verifiable formal features, which again are historically grounded in both theory and practice. ${ }^{35}$ Here I wish only to draw attention the complex structure of the B-Text that amply illustrates that sophisticated plotting antedates Shakespeare.

Once the misplaced comic scene between Rafe and Robin in the B-Text was restored to its correct position, ${ }^{36}$ the following distribution of settings was revealed (Figure 1).

Additionally, in the first series of Wittenberg scenes (1-7), the action changes between tragedy and comedy, whereas the final Wittenberg part is constituted by three tragic scenes. This type of systematic arrangement of scenes and modes is matched by a similarly controlled double time frame found in the B-Text only, an array which frames the twenty-four years of Faustus' compact with Lucifer as described in Figure 2.

The outer frame breaks down in the A-text, which does not have the final discovery scene in the morning following Faustus's death at midnight. Similarly, the internal distribution of scenes is messed up in the edition of 1604 due to the substantial cuts in the play's middle part. ${ }^{37}$ The situation is somewhat comparable with the relationship between A Shrew and The Shrew, but the text printed in The Folio does not exhibit the controlled design of $A$ Shrew.

As the topomorphical analysis of Doctor Faustus (B) clearly shows Marlowe can handle several plots simultaneously and create significant patterns of loco-temporal distribution, including a framing structure. ${ }^{38}$ In A Shrew, too, the main action concerning the taming of Kate is given a significant framing structure by being introduced by a traditional comic motif according to which a lord dupes a drunken tinker, Sly, into believing that he is a lord and instructs his servants to wait upon him and act him a comedy. The comedy that Sly is to watch is of course a comedy entitled "The taming of a shrew" (1.64). The dramatist has thus created a meta-dramatic situation that facilitates the

Figure 2

\begin{tabular}{|c|c|c|c|c|}
\hline $\begin{array}{l}\text { outer } \\
\text { frame }\end{array}$ & $\begin{array}{l}\text { inner } \\
\text { frame }\end{array}$ & $\begin{array}{l}\text { (the } 24 \text { years of } \\
\text { of the compact) }\end{array}$ & $\begin{array}{l}\text { inner } \\
\text { frame }\end{array}$ & $\begin{array}{l}\text { outer } \\
\text { frame }\end{array}$ \\
\hline $\begin{array}{l}\text { morning /dinner } \\
{[1-3]}\end{array}$ & midnight & & supper/midnight & $\begin{array}{c}\text { morning } \\
{[20]}\end{array}$ \\
\hline & [5] & & [18-19] & \\
\hline
\end{tabular}


presentation of the main play on the topic of taming as it were through an illusionistic filter. The main body of the play is lodged within a comic framing device, and the author maintains the meta-dramatic effect throughout by making Sly comment on the action as many as three times from his privileged position on the stage, thus disrupting the illusion of reality. Also, he sits on the stage as a reminder of that illusion. This makes the play itself an illusion that is doubly distanced from the "real" world and that can been seen as a defensive move on the dramatist's part to exculpate himself against attacks for being too provocative.

The first plot encountered inside the frame is a conventional comic plot focused on two young students, Polidor and Aurelius, and two young daughters, Emelia and Phylema, of a wealthy merchant Alonso. Their road to love and marriage is blocked by Alfonso who

hath solemnlie sworne,

His eldest daughter first shall be espowsed,
Before he grauntes the yoongest leave to love (4.16-18)

The true obstacle is the headstrong and independent Kate, who is repeatedly referred to as "the divell himselfe" and "a skould" (4.22; 23). The second internal plot, being the principal one, therefore treats the seemingly impossible task of taming Kate by the adventurous Ferando, who has been enlisted by Polidoro to court and marry Kate so as to make possible his own marriage to Emilia, one of the younger sisters. Thus The Taming of a Shrew has a structure of plot-withinplot-within-plot that suggests more than a general knowledge of literary composition. The play's loco-temporal distribution bears witness to a control in the overall design that is not always present in Renaissance plays. The first scene is set outside a tavern, where Slie is discovered sleeping, then the action moves to an unspecified hall in the Lord's Manor, where the performance of 'the taming of the shrew' takes place that is nearly the entire play except its final short scene.

\section{Figure 3}

outside

an ale-house

[1] outside

an ale-house

[19]

inside the Lord's Manor [2-18]

[Athens \{country\} Athens \{country\} Athens \{country\} Athens \{country\} Athens]
[3-8]
[9]
[10]
[11]
[12]
[13]
[14]
[15] [16-18] 
Subsequently the acting space represents a number of different settings: Athens, Ferando's country house, the road to Athens, Athens, and finally the action returns to the tavern encountered in the first scene: In the following graph we see how these settings are distributed symmetrically (Figure 3).

The dramatist expertly places the protagonist's arrival at Ferando's country house, the site of the "taming school", exactly halfway through the play (in scene 9), so at the heart of the comedy we enter if not the "green world" of Shakespearean comedy, but one of permissiveness, carnival, and metamorphosis where Ferando deliberately acts the fool. Sanders's account of his master's dress and behaviour tells it all;

He puts on an olde Jerkin and a paire of canvas breeches down to the Small of his legge and a red cap on his head and he Lookes as though wilt burst thy selfe with laffing When thou seest him. He's ene as good as a Foole for me: ... (9: 11-16)

Ferando is in other words dressed to be "even like a madman" (9: 8) and fool in the upcoming scenes in the taming school. The audience would therefore have expected farce and extravagant behaviour in the country house scenes, ${ }^{39}$ and the on-stage spectator Sly correctly identifies Ferando as "the Fool" when he enters in scene xv. His outrageous behaviour at the country house suggests that he plays the part of the homo sylvarum, or wild man, ${ }^{40}$ typical of summer festivals, or alludes to a Commedia dell'arte character, like Harlequin. ${ }^{41}$ That he is deliberately play-acting is clear when in a soliloquy addressed to the audience he announces that "This humour must I holde me a while" (9.42). The use of a symbolic, if not festive, setting for the taming shows us the dramatist's thoughtful control of settings and plots as the action shifts between town and country and between parody of Romantic comedy and plain farce. In the world of the taming school, Ferando is Lord of Misrule and everything is turned upside down. Abuse masquerades as love, brutality as care, the moon becomes the sun, and an old man becomes a maid. The dramatist's command is no less than impressive, and to my mind it is matched closely by the carefully plotted structure of settings and loco-temporality in Doctor Faustus (B)

We noted above that the beginning and the conclusion of the plots in A Shrew are arranged symmetrically. Following the Sly material at the beginning of the play, the lovers' plot is initiated when Polidor welcomes Aurelius to Athens (scene 3), the second love plot (i.e. the taming) begins when Ferando enters together with his man Saunders (scene 4.70-100) and the first of comic intermezzi between Saunders and Polidor's Boy follows after the wooing scene (scene 8) and the second, and last, immediately before the marriage (5.93). This order of events, or "places of action" is reversed at the end of the comedy, where Ferando and Kate leave first, to be followed by the other lovers, before Slie is carried in for the final scene in his own clothes (Figure 4).

The fact that the taming occurs within a dramatic frame and that it foregrounds elements of feasting and role changes connected with 
popular customs ${ }^{42}$ suggests a

context for the taming of the

heroine. As is well known, one way

of disrupting the constrictions of imposed patriarchal gender

categories in comedy is by

importing the green world of

popular festivals into plays. C.L.

Barber has shown how strongly

traditional customs condition the

shape of Elizabethan comedy, ${ }^{43}$

offering the spectators a space for freedom and metamorphosis. Moreover, we note that Kate and Ferando leave for the latter's "countrie house" (5.75), thus suggesting that in what follows ordinary rules will be suspended. Ferando dresses in a conspicuously odd fashion, indicating that he in the crucial taming scene will assume the role of a jester. His behaviour may have triggered different audience expectations, but all spectators would have expected something outrageous to happen. The escape into "the green world" where ordinary rules do not apply is in fact suggested, when the "countrie house" is mentioned as many as three times (5.50; 5.70; 5.132) and his unconventional, clown-like costume is similarly hinted at twice and specified on two occasions: he is "baselie attired, and a red cap on his hed"(7.23), wearing "an old Jerkin and a paire of canvas breeches down to the small of his legge and a red cap on his head" (9.11-13) Saunders even refers to his behaviour as that of a "Foole" (9.16). In other words the dramatist makes sure that the audience gets the information required to interpret the stage situation. The arena of Ferando's play-acting also extends to the

\section{Figure 4}

1. Sly plot

2. The lovers' plot

3. The taming plot

4. The comic intermezzi

3. The taming plot

2. The lovers' plot

1. Sly plot

highway: as seen when he encounters the Duke of Cestus and deliberately "mistakes" him for a young girl. In accordance with the metamorphoses that may happen within the green world, the Duke thinks he has been "transformed" (15.44) and Fernando and Kate hurry after him "to perswade him into his shape againe" (15.55). This clearly suggests the shapechanging power of performance in the play. Kate's performance at this point shows that she has grasped the motivation behind Ferando's strange behaviour, and when she outdoes him in her preposterous identification he openly declares his love for her:

Why so Kate this was friendly done of thee, And kindly too: why thus must we two live, One mind, one heart, and one content for both. (15.49-51)

In one sense she has matched his madcap performance by surpassing his jesting: When the couple arrive to participate at the festivities in connection the wedding of Emilia and Polidor and Phylema and Aurelius, they are agreed to keep up the act with the intention of baffling and 
tricking. It is ironic that it is Aurelius who proposes a wager to which of the three newlywed women is quickest to respond to their husband's call. Thus this new wager draws attention to the earlier wagers which set the action of $A$ Shrew going. The focus on wagers unite the different plots and also produces the comic resolution, another example of a consistent pattern embedded in the action.

The dramatist is in full control of his characters and stresses performativity to an unexpected degree in the way Kate and Ferando speak and act. The patriarchal pattern of social moulding and circumscription is in place, but it has been modified so as to allow some freedom of action and performance. The author is careful to lessen the severity of the pattern both from without, that is, by means of the meta-theatrical frame, as well as from within by showing us Kate as a daredevil who is willing to take on a challenge and perform a role nobody thinks she is capable of. She is thus more than the conventional Elizabethan shrew and scold, but one who to no little extent is empowered, although at a risk. In an aside immediately after she has complained about Ferando to her father, she informs the audience of her intention to go along with the marriage as a kind of wager with her and the spectators:

But yet I will consent and marrie him

For I methinks haue liude too long a maid,

And match him to, or else his manhoods good (5.40-42)
Ann Thompson comments on the wooing scene that " $t]$ hus it is made explicit that (a) Katherina can see some positive advantage in marrying [...], and that (b) she is going to relish competing with him." ${ }^{44}$ She also undoubtedly feels sexually attracted to her unconventional suitor. Kate in the scene displays no open, physical struggle against the proposed marriage plans, whereas in The Shrew her reaction is both physical and verbal and the treatment of her more consistently physical and insensitive. In $A$ Shrew gender boundaries are "more fluid" and there is a far greater focus on the exchange of roles. ${ }^{45}$ At every point when Kate protests, Ferando persuades her by declarations of love and with promises of favours to follow. No physical threats are made. To my mind what causes Kate to make the wager in an aside to the audience, is Ferando's statement a few lines earlier. Here he confesses to wanting Kate the way that she is: “... they say thou art a shrew,/And I like thee better for I would have you so." (5.25-26), and his words obviously make an impression. This surely is a novel and provocative conception of the relationship between man and woman in wedlock, and it is one that the author carefully couches within the meta-dramatical frame involving Sly.

As I have argued above, there is nothing in terms of the plot structure, or dispositio, in $A$ Shrew to suggest an inept "compiler," nor that there were no plays available before Shakespeare to show a comparable mastery of composition. The disposition of scenes uncovered here contrasts with the negative characteristics attributed to the play by nearly all modern editors, who have treated "A Shrew ... 
not as an artistic structure with its own patterns of meaning and its own dramatic logic, but as a heap of shards thrown together by ignorant actors with no capacity for coherence." 46 Similarly, as the plot and loco-temporal patterning of Doctor Faustus (B) shows, examples of sophistication in the arrangement of plots were available before Shakespeare enters the scene. The question now remains whether the writer's command of language, or the composition and embellishment of speeches, bear evidence of a corresponding finish and coherence?

A common way of discrediting an awkward text that does not "fit" into the accepted picture has been to heap abuse on the anonymous author and his product. Graham Holderness and Bryan Loughrey counter this type of criticism against dramatist of $A$ Shrew, who is said to be "inept" and "incompetent," and who writes "execrable" and repetitive blank verse. ${ }^{47}$ Marcus also argues that A Shrew may be "less explicit," "less accurate," and less "eloquent," but rather than being a corrupt text, it is "different" from The Shrew. ${ }^{48}$ Miller, who also is sympathetic to the idea that $A$ Shrew is a text with its own rationale, still uses the terms "compiler" and "plagiarist" and finds the play "derivative," denying the author the capacity to produce a dramatist capable of a cohesive work. Holderness and Loughrey on the other hand dismiss such views by pointing to instances in which A Shrew demonstrates better readings, where A Shrew and The Shrew are close. ${ }^{49}$

I do not wish to enter into the question of authorship here, as I have written on that topic elsewhere. ${ }^{50}$ I will instead concentrate on one aspect of composition in which A Shrew differs markedly from The Shrew, and that shows the dramatist's control of dialogue: his striking use of periodicity in speech construction. In this the dramatist of the earlier play shows himself to practice a compositional technique that Marlowe had introduced to the Elizabethan stage. If we carry out an analysis of how he composes his speeches, we will learn just how unified or disjointed his style of writing is, as well as an indication of when the play was written.

In Dido and Tamburlaine the Great Marlowe establishes a style of speech composition based on "a poetics by contrivance and artful combination." 51 Although reference is constantly made to his "mighty line," it is Marlowe's speeches that were to serve as a model for his contemporaries, not "the mighty line" alone. Everybody seems to have imitated his style, but Shakespeare is the most prominent example of a dramatist who imitates his speech construction, when he adopts the technique, for example, in King John. ${ }^{52}$ The style involves creating strongly jointed speeches by treating them as if they were complete rhetorical periods. Briefly, speeches consisting of several periods, or complete sentences, were given holistic rhetorical patterning that emphasized them as finished units of communication with a well-defined beginning middle, and end. I have written more fully on this phenomenon elsewhere ${ }^{53}$ and will here only give one example from Tamburlaine, Part Two that illustrates well Marlowe's innovative speech construction, rooted in periodicity by means of extrasyntactic verbal repetitions. ${ }^{54}$ It is Tamburlaine's final speech to his heir, Amyras (Figure 5; emphases added): 


\section{Figure 5}

Tamburlaine.

So, reign my son; scourge and control those slaves,

a myson

Guiding thy chariot with thy father's hand.

As precious is the charge thou undertak'st

As that which Clymene's brain-sick son did guide,

When wandering Phoebe's ivory cheeks were scortched,

And all the earth, like Aetna, breathing fire.

Be warned by him; then learn with aweful eye

To sway a throne as dangerous as his;

For if thy body thrive not full of thoughts

As pure and fiery as Phyteus' beams,

bc Guiding thy chariot

d undertak'st

The nature of these proud rebellious jades

Will take occasion by the slendrest hair

And draw thee piecemeal, like Hyppolitus,

Through rocks more steep and sharpe than Caspian cliffs.

The nature of thy chariot will not bear

A guide of baser temper than myself,

More than heaven's coach the pride of Phaeton.

Farewell, my boys! My dearest friends, farewell!

e fire

throne: topos of sovereignty

e fiery

d take occasion

c thy chariot

$\mathrm{b}$ guide

a my boys

Tamburlaine, Part Two, 5.3.224-46

Embedded and fixed in the flow of the speech, which also is an example of emblematic rhetoric (Phaeton), is a foregrounded series of five words, that are repeated with inversion on the formula a-b-c-d-e-// e-d-c-b-a, so that they form a macro-chiasmus or a recessed symmetrical pattern around the central mention of the throne:

my son/Guiding thy chariot/undertak'st/fire//

fiery/take/thy chariot/guide/my boys

The speech ends with a rhetorical flourish of the kind Marlowe bestows on Dido in her final speech, while Tamburlaine's final line is made to end with a chiasmus: "Farewell, my boys! My dearest friends, farewell!" (245). Tamburlaine retains his capacity to speech like "Hermes, prolocutor of the gods" (Part One, 1.2.210) but despite the display of imagery from classical myth and literature, combined with rhetorical ornamentation, he cannot cast a spell on the future and Amyras's reign is ill-fated.

In accordance with Aristotle's discussion in The Art of Rhetoric, here too, a combination of three verbal figures ${ }^{55}$ work across syntactic borders to produce a pattern of periodicity. These repetitions are thus extrasyntactic, even though the template derives from the ornamental apparatus of the grammatical period. In the above example, the Aristotelian formula for wholeness has been applied to create a controlled but dynamic speech. Despite the dialectic and progressive linearity that naturally 
inheres in dramatic dialogue, the separate elements in its progressive flow combine to form one well-disposed and framed verbal construct, "one poem's period" (Tamburlaine, Part One, 5.2.107) to quote the dramatist himself. Such speeches thus display the characteristics of stanzas, the "rooms" of poetry, and therefore can be analysed and discussed in terms of spatial form as suggested by the quote from Ben Jonson, above. When a method of pattern recognition was applied to Marlowe's plays, it was ascertained that his compositional style is permeated by a sizeable proportion of periodicity; in Tamburlaine, for example, such speeches cover $30 \%$ of the text in Part One, and $24 \%$ in Part Two. In Dido the figure is $21 \%$, whereas in Doctor Faustus (B) the percentage is nearly 19 (18.7).56 This is a type of speech construction that Shakespeare began to practice in King John shortly before or in $1590 .^{57}$

Tamburlaine's curtain speech and others of its kind constitute speech acts or in Jonsonian terminology "places of action" and behave like stanzas, the "rooms" of poetry. It goes without saying that not all speeches are as elaborate in their rhetorical patterning as that cited, some are more patterned and many more considerably less patterned, or not at all. However, the general pattern is that verbal figures are deployed to provide linkage between the beginning, the middle and the end of speeches, that in this manner have been treated formally like a period. It so happens that this is also the situation in $A$ Shrew, where as much as $31 \%$ of the text displays periodicity in its speeches. ${ }^{58}$ This firmly places $A$ Shrew in terms of style and time of composition in the late 1580s together with Dido, the two Tamburlaine plays, and Doctor Faustus (B). ${ }^{59}$ I will give one example, the speech at 17.116-125, in which the Duke of Cestus takes farewell of Alsonso (Figure 6).

In this highly formalised reply he objects to the informality of the situation and the breach of princely decorum. This he also shows by marshalling his words into a rigid pattern (a-b-a-

\section{Figure 6}

Duke. Thanks good Alonso: but I came alone,

And not as did beseeme the Cestian Duke,

a

bc

Nor would I have it knowne within the towne,

That I was here and thus without my traine,

But as I came alone so will I go,

And leave my son to solemnise his feast,

And ere't belong Ile come againe to you,

And do him honour as beseemes the son

of mightie Jerobell the Cestian Duke,

Till when Ile leave you, Farewell Aurelius.

(A Shrew, 17.116-24) 
c-b-c) that emphasizes his own singularity ("But as I came alone so will I go"). The repetitions are multiple examples of epanados and epanalepsis ("not as did beseeme the Cestian Duke" vs "as beseemes ... the Cestian Duke"). As a point of general interest, characters of rank (like the Duke) or in a powerful position exhibit more rhetorical repetitions than more humble characters. ${ }^{1}$

Turning next to Kate's final speech on obedience, it is the longest periodically structured speech in A Shrew, which should not come as a surprise given her empowerment as a result of the agreement with Ferando in scene 15:60

Then you that live thus by your pompered wills, Now list to me and marke what I shall say: Th' eternall power that with his only breath Shall cause this end and this beginning frame, Not in time, nor before time, but with time, confusd, For all the course of yeares, of ages, moneths, Of seasons temperate, of dayes and houres Are tund and stopt, by measure of his hand, The first world was, a forme, without a forme, A heape confusd a mixture all deformed, A gulf of gulfes, a body bodiles,

Where all the elements were orderles, Before the great commander of the world, The King of Kings, the glorious God of heaven. Who in six daies did frame his heavenly worke, And made all things to stand in perfit course. Then to his image did he make a man, Olde Adam and from his side asleepe A rib was taken, of which the Lord did make The woe of man so termed by Adam then, Woman for that, by her came sinne to us, And for her sin was Adam doomd to die, As Sara to her husband, so should we Obey them, love them, keepe, and nourish them,
If they by any meanes doo want our helpes, Laying our handes under their feete to tread, If we by that we, might procure there ease, And for a president Ile first begin, And lay my hand under my husbands feete.

(A Shrew, 18, 15- 43; emphases added).

Rather than "compiling" various bits into speech, the dramatist here carefully structures the 29-line speech where Kate performs the role of a female Tamburlaine, a veritable scourge of her two silly and willful sisters, who refuse to come at their husband's call. The speech, which has a clear logical structure from the initial twoline address to Emilia and Phylema to the twoline exemplum of subjection enacted by Kate, consists of two parts, recalling the bi-partite form of periodic sentences (protasis and apodosis). The first part is on creation of a divinely ordered world, whereas the second focuses on the creation of man and the necessity to impose order after Eve brought sin into the world. The initial, central, and final positions of the speech are linked by thematic and verbal repetitions joining the beginning (by means of epanalepsis) to the end and the beginning to the middle (by means of epanados). ${ }^{61}$ Repeated key words form the following basic structure:

Beginning frame // did frame // begin

Here the use of the verb "frame" may refer to the embedded structure by being a technical rhetorical term in English Renaissance terminology, meaning "to compose" in text. These verbal linkages are further underpinned by a strong thematic nexus between the opening 
and the middle. Kate opens with a reference to "Th' eternal power" (17) that made the world, which she then echoes in three synonyms at the centre of the speech: "The great commander of the world,/The King of Kings, the glorious God of heaven"(27-28). This centrally placed tribute to the triune deity is given prominence by being itself framed by antithetical statements illustrating the intervention of the deity in a world without order: "all the elements were orderles" (26) are balanced by "made all things to stand in perfit course" (30). The author has cleverly fashioned a place of verbal action, a room of poetry, that at surface level presents a submissiveness that seems to be the very opposite of Kate's newly gained freedom to play within the role, but that in reality is aimed at mocking her sisters and making Ferando win the wager. The taming is therefore provocatively turned away from herself against the conformist values of her father, her sisters and their husbands. Holderness and Loughrey speculate that A Shrew "might well have been offered as a challenge and provocation to debate rather than as an attempt at ideological incorporation" (29).

In this context, the use of Guillaume de Salluste, Sieur Du Bartas' popular work, La Création du Monde ou Première Sepmaine (1578) appears to be a deliberate strategy and not a "strange case."62 It is clear, Miller writes in a comment on the lines inspired by Du Bartas, that Joshua Sylvester's translation of the work is "not the source of the English version used by the compiler of A Shrew" (148), but he does not consider the possibility that the author could himself be the translator. The problem is unsolved, but Richard Hillman has suggested that "the translator of the passage as found in $A$ Shrew was well informed about the religious controversy surrounding the use by Du Bartas of the pagan term "Chaos" since he drops that line in the passage translated, ${ }^{63}$ which suggests that the translation, too, is part of a consistent strategy chosen by the author. It is therefore appropriate to remember that Marlowe gives to Du Bartas, named Bartas, "a small but ardent role as one of Henry of Navarre's advisers" in The Massacre at Paris. ${ }^{64}$ So when we consider that A Shrew has "a smoother rendering" (Miller 149) of Du Bartas than Joshua Sylvester, and add that it is in blank verse, this and the presence of Marlovian vocabulary in the speech could perhaps be said to further the candidacy of Marlowe as "the compiler."

The unexpected reworking of La Sepmaine in Kate's speech of triumph over her sisters and father must have been particularly enjoyable to those in the audience acquainted with Du Bartas' popular work, and who were "highly skeptical of such propagandist rhetoric."65 The speech serves several purposes apart from completing the plot of taming, transformed into a trickster plot at the cost of patriarchy and convention. At the same time, a censor reading, not watching, the play would have found a text in which a conventional ending was sealed with a conformist statement drawn from the impeccably orthodox text of Du Bartas. Besides, the provocative inner play of taming is tucked safely within the Sly plot, which as Sly puts it to the Lord “... this is but the play, they're but in jest (16.5). In the playhouse, moreover, the reception depends on how the speech was acted, for in view of how A Shrew is plotted with a 
series of three wagers before the fourth and final one, it is hard to believe in Kate's sincerity during her great speech.

\section{Conclusion}

As argued above both in terms of dispositio and elocutio, that is, plotting and speech elaboration, A Shrew can be shown to have an embedded "formal intention" that suggests it to be a carefully designed artistic whole. In fact, in terms of style, structure, and theme it reveals features typical of Italian comedy, a fact further underpinned by the material lifted from Gascoigne's translation of Ariosto's I Suppositi.66 Then, too, plays inspired by Italian comedies are generically mixed in having double plots featuring resourceful heroes and heroines. For instance, heroines in Italian bourgeois drama display wit and have a resourcefulness and a sexual appetite of their own in the tradition of Boccaccio, ${ }^{67}$ and they are often put to the test and confronted in plot situations that are far removed from the ideals of Shakespearean love comedy. ${ }^{68}$ A Shrew fits this pattern, for it is clear that Kate here is performing a scandalous scene of subjection to the conditions historically imposed upon gender by patriarchy - even back to Eve and Sara. The scandal in A Shrew, however, is not that Kate subjects herself to the expectations of patriarchy, but her provocative performance when she plays the role of a "tamed" woman. Hers is a tongue-in-cheek performance we enjoy and we thoroughly applaud the way the trickster couple win the wager by means of their collaborative trickery.

The Shrew and A Shrew may be "twinned histories" and the texts' interaction over time may have created what Hodgdon terms "the Shrew complex or syndrome," 69 but that is essentially the work of editors and directors bent on defending the Bard and salvaging the incomplete text printed in the Folio. Thus the shadow of the Folio has been allowed to obscure the qualities of an original provocative and "progressive" comedy ${ }^{70}$ that may tell us a lot about the reception of Italianate comedy on the London stage in the late 1580s.

\section{Works Cited}

Allen, Michael J. B. and Muir, Kenneth (eds). Shakespeare's Plays in Quarto: A Facsimile Edition of Copies Primarily from the Henry E. Huntington Library. Berkeley: University of California P, 1981.

Barber, C.L. Shakespeare's Festive Comedy. A Study of Dramatic Form and its Relation to Social Custom, Princeton, New Jersey: Princeton University Press, 1959.

Bevington, David and Rasmussen, Eric (eds). Doctor Faustus: A- and B-texts (1604, 1616). Manchester: MUP, 1993.

Boas, F. S. (ed). The Taming of A Shrew. London: Chatto and Windus, 1908.

Boose, Linda E. “Scolding Brides and Bridling Scolds: Taming the Woman's Unruly member," Shakespeare Quarterly, 42: 2, 1991: 179-213. 
Bjørnstad, Hall (ed.). Borrowed Feathers. Plagiarism and the Limits of Imitation in Early Modern Europe, Oslo: Unipub, 2008.

Bloom, Harold. William Shakespeare - Comedies, New Edition - Bloom's Modern Critical Views, New York: Chelsea House, 2009.

Bradley, David. From Text to Performance in the Elizabethan Theatre. Cambridge: CUP, 1991

Brunvand, Jan Harold. “The Folk Tale Origin of The Taming of the Shrew," SQ 17, 1966: 345-59.

Bullough, Geoffrey (ed).. Narrative and Dramatic Sources of Shakespeare. 8 vols. London and New York: Routledge, 2002.

Castagno, Andrea C. The Early Commedia dell'Arte 1520-1621. The Mannerist Context, New York: Peter Lang, 1994.

Coffin, George Taylor. "The Strange Case of Du Bartas in The Taming of a Shrew," part 2 of "Two Notes on Shakespeare," $P Q$ 20, 1941: 373-6.

Dolan, Frances E. (ed). The Taming of the Shrew: Texts and Contexts. Boston and New York: Bedford/St. Martin's, 1996.

Eriksen, Roy. "Ars Combinatoria: Marlowe and the Art of Framing." In Variations sur la lettre, le mètre e la mésure: Shakespeare, ed. Dominique Goy-Blanquet. Amiens: CRDP de l'Academie d'Amiens, 1996: 111-26.

---. The Building in the Text: Alberti, Shakespeare, Milton. University Park, Penn.: Penn State P, 2001.

---. The Forme of Faustus Fortunes: A Study of The Tragedie of Doctor Faustus (1616). Oslo and Atlantic Highlands, Conn.: Solum and Humanities Press, 1987.

---. "Falstaff at Midnight: The Metamorphosis of Myth," in eds. Janet Clare and Roy Eriksen. Contexts of Renaissance Comedy, Oslo: Novus Press, 1997: 124-47.

---. "Friends or Foes. Marlowe and Shakespeare as Rivals in the Republic of Letters," in Hall Bjørnstad (ed.) Borrowed Feathers. Plagiarism and the Limits of Imitation in Early Modern Europe, Unipub: Oslo, 2008, 191-200.

---. "The Misplaced Clownage-Scene in The Tragedie of Doctor Faustus (1616) and Its Implications for the Play's Total Structure." English Studies 17. 1981: 249-58.

---."Poetics, Stylometrics and Attribution: Periodicity in the Central sequences in Marlowe's Doctor Faustus (B)," Approaches to the text: From Pre-Gospel to Post-Barque, ed. Roy Eriksen and Peter Young, Early Modern and Modern Studies vol 10, Pisa and Rome: Fabrizio Serra Editore, 2014, 71-90.

--.. "The Taming of a Shrew: Composition as Induction to Authorship." NJES 4.2(December 2005), 41-61. Reprinted in ed. Harold Bloom, William Shakespeare - Comedies, New Edition - Bloom's Modern Critical Views, New York: Chelsea House, 2009, 77-95

--.. “'What resting place is this?' Aspects of Time and and Place in Doctor Faustus (1616), Renaissance Drama. 16, 1985, 49-74.

Gibbons, Brian. Shakespeare and Multiplicity, Cambridge: Cambridge University Press, 1993. 
Goy-Blanquet, Dominique. Shakespeare. Variations sur la lettre, le mètre et la mesure, Paris: Société Shakespeare Francaise, 1996.

Greg, W. W. (ed.). 1950. Marlowe's Doctor Faustus, 1604-1616. Oxford: Clarendon Press.

Guillaume de Salluste, Sieur Du Bartas, La Création du Monde ou Première Sepmaine (1578), in Urban Tigner Holmes, Jr et al, The Works of Guillaume de Salluste, Sieur Du Bartas: A Critical Edition with Introduction, Commentary and Variants, 3. vols Chapel Hill, N.C.: University of North Carolina, 1935-40, volume 2 .

Hillmann, Richard. "La Création du Monde et The Taming of The Shrew: Du Bartas comme Intertexte," Renaissance and Reformation 27. 1991: 249-580.

Holderness, Graham and Loughery, Brian (eds). A Pleasant Conceited Historie, Called The Taming of A Shrew. Eastbourne: Pearson Education, 1992.

Hosley, Richard. "Sources and Analogues to The Taming of the Shrew." Huntington Library Quarterly 27. 1964, 289-308.

Hosley, Richard (ed.). The Taming of the Shrew. Gen. ed. Alfred Harbage. Complete Pelican Shakespeare: The Comedies and the Romances. Harmondsworth: Penguin, 1981.

Irace, Kathleen 0. Reforming the 'Bad' Quartos: Performance and provenance in Six Shakespearean First Editions, 1994.

Laroque, Francois. Shakespeare's Festive World: Elizabethan Seasonal Entertainment and the Professional Stage. Cambridge: CUP, 1993.

Maguire, Laurie E. Shakespearean Suspect Texts: The 'Bad' Quartos and Their Contexts. Cambridge: CUP, 1996.

Maguire, Laurie E. and Berger, Thomas L. (eds.). Textual Formations and Reformations. Newark: University of Delaware Press, 1998.

Marcus, Leah. "The Shakespearean Editor as Shrew-Tamer." English Literary Renaissance 22.2. 1992. 177-200.

---. Unediting the Renaissance: Marlowe, Shakespeare, Milton. London and New York: Routledge, 1996.

Marlowe, Christopher. Tamburlaine the Great. London: Richard Jones, 1592.

Miller, Stephen Roy. 1998. "The Taming of a Shrew and the Theories; or, 'Though this be badness, yet there is method in' t,"' in Maguire and Berger (eds). 251-63.

Mulder, John R. The Temple of the Mind, New York: Pegasus, 1969.

Pettitt, Thomas. “The Folk Play in Marlowe's Doctor Faustus." Folklore 91, 1980: 72-79.

Pettitt, Thomas. "Formulaic Dramaturgy in Doctor Faustus. Eds. Kenneth Friedenreich et al. "A poet and a filthy play-maker": New Essays on Christopher Marlowe. New York: AMS, 1988: 167-191.

Pettitt, Thomas. "Towards the Zielform: Oral Transmission and the Reshaping of Marlowe's Plays." Comparative Drama 39.2, 2006: 213-24

Prescott, Ann Lake. "The Reception of Du Bartas in England," Studies in the Renaissance 15 (168), 152. Rose, Mary Beth, "Sexual Love in Elizabethan Comedy," Renaissance Drama, n.s. XV, 1984: 1-29. 
Salingar, Leo. The Traditions of English Renaissance Comedy. Cambridge: CUP, 1976.

Seronsy, Cecil C. "'Supposes' as the Unifying Theme in The Taming of the Shrew," Shakespeare Quarterly 14, 1963: 15-30.

Shakespeare, William. The Taming of the Shrew, ed. Ann Thompson, New Cambridge Shakespeare. Cambridge: CUP, 1984.

Scott, William, The Model of Poesy, edited with an Introduction and commentary by Gavin Alexander, Cambridge: CUP, 2013.

Urkowitz, Stephen. “Good News about Bad Quartos.” Ed. Maurice Charney. 'Bad' Shakespeare: Revaluations of the Shakespeare Canon. London and Toronto: Associated UPs, 1988.

Werstine, Paul. "Touring and the Construction of Shakespeare Textual Criticism," in Maguire and Berger (eds). 1998: 45-66.

Van Es, Bart. Shakespeare in Company, Oxford: OUP, 2013.

Wiggins, Martin. Drama and the Transfer of Power in Renaissance England. Oxford: OUP, 2012.

${ }^{1}$ A Pleasant Conceited Historie, Called The Taming of a Shrew, eds. Graham Holderness and Bryan Loughrey. Harvester Wheatsheaf: Hemel Wheatsheaf, 1992,16.56. I cite the text and use the the scene divisions in Geoffrey Bullough, Shakespeare's Dramatic and Narrative Sources, 4 vols, I.69-108.

2 Martin Wiggins, Drama and the Transfer of Power in Renaissance England. Oxford: Oxford University Press, $2012,1$. 3 W.W. Greg, Marlowe's Doctor Faustus, 1604-1616, Oxford: Clarendon Press, 1950, 61-62.

4 Bart van Es, Shakespeare in Company, 102.

5 See the account in Stephen Roy Miller, The Taming of a Shrew. The 1594 Quarto, The New Cambridge Shakespeare. The Early Quartos, Cambridge: CUP, 1998, "Introduction," 1, 51-55.

${ }^{6}$ See Hodgdon's account of Michael Bogdanov's RSC production of 1978, The Taming of the Shrew, The Arden Shakespeare, London: Methuen, 2010, "Introduction," 111-13. The production "anticipated feminist, new historicist and cultural metrialist criticism, that during the twentieth century's last decades, would shine an increasingly brilliant spotlight on The Shrew." (113)

7 Together with The Two Noble Kinsmen and Two Gentlemen of Verona, "Titus Andronicus, and The Taming of the Shrew stand out among Shakespeare's early plays," argues Brian Gibbons, "for their capacity to shock," in being characterized by "a special harsh quality." Shakespeare and Multiplicity, Cambridge: CUP, 1993, 79.

8 Barbara Hodgdon, "Introduction," 38.

${ }^{9}$ In her otherwise well-balanced and forcefully argued edition, Barbara Hogdon, spends 62 pages on performance, "Introduction," 71-131.

${ }^{10}$ As critics we are readers looking for the formal intention embedded into the flow of the text in order to process the offered information, and Marlowe provides a clue to where we should look to find our bearings when he draws attention to periodicity, as a shaping force and template in Early Modern texts. Cf. "Poetics, Stylometrics, and Attribution: Periodicity in Marlowe's Doctor Faustus (1616), in eds Roy Eriksen and Peter Young, Approaches to the Text: From Proto-Gospel to Post-Baroque, EMMS vol, 9, 171-90. Pisa and Rome: Fabrizio Serra Editore, 2014, passim. 11 Holderness and Loughry, passim.

12 "Falstaff at Midnight: The Comic Metamorphoses of Myth," in Contexts of Renaissance Comedy. Oslo: Novus, 1997, $114-134(130)$.

13 Miller, "Introduction," 10.

14 Leo Salingar, The Traditions of English Renaissance Comedy, Cambridge: CUP, 1972, p. 272.

15 The two comic intermezzi with Boy and Sanders can hardly be said to constitute an independent plot, but would be examples of the category of "fond and frivolous gestures" complained about by the editor of Marlowe's Tamburlaine.

16 The Taming of the Shrew, ed. Ann Thompson, Cambridge: Cambridge University Press, 1984,

"Textual analysis," 166.

17 Thompson, The Taming of the Shrew, "Introduction," 2, and Miller, The Taming of a Shrew the 1594 Quarto,

"Introduction," 3

18 Hodgdon, "Introduction," 35. 
19 The Taming of the Shrew, The Complete Pelican Shakespeare. The Comedies and the Romances, Gen. Ed. Alfred Harbage, Harmondsworth: Penguin, 1981, "Introduction," 31.

${ }^{20}$ Miller points out "that although the love story of the shrew's two sisters is simpler than the Bianca plot of The Shrew, A Shrew does contain another coherent plot strand not found in The Shrew." 7-8.

21 Miller, "Introduction," 11; 16

22 Miller, "Introduction," 11.

23 Miller, "Introduction," p. 3.

24 Kathleen O. Irace, Reforming the 'Bad' Quartos: Performance and provenance in Six Shakespearean First Editions, 1994.

25 See Miller's account of the Bad Quarto debate in his "Introduction," 1-12.

${ }^{26}$ Holderness and Loughrey, 15-25.

27 Leah Marcus, Unediting the Renaissance: Marlowe, Shakespeare, Milton, London and New York, 1996, 128.

28 John Bakeless, The Tragicall History of Christopher Marlowe, 2 vols., Hamden, Conn.: Archon Books, 1964, II: 215.

${ }^{29}$ Ben Jonson, Timber, or, Discoveries, Syracuse, N.Y.: Syracuse University Press, 1976, 92-93.

30 William Scott writes: "in our 'Model of Poesy' we must proceed (if we will proceed orderly) first to lay the

foundation, to define it in general; which explaned we may show, by division, how all several kinds of poetry as the divers rooms and offices are built theron, how the general is dispensed into the particulars, how the particulars are sundered by their special differences and properties, that as walls keep them from confounding one in another; and lastly what dressing and furniture best suits every subdivided part and member, that thereby direction may be given how to work in which of the kinds our nature shall inform us we are most apt for. And this is the period of discipline and farthest scope". The Model of Poesy, edited with an Introduction and commentary by Gavin Alexander, Cambridge: Cambridge University Press, 2013, 5.

${ }^{31}$ Quoted from Roy Eriksen, The Building in the text. Aberti to Shakespeare and Milton. University Park, Pa: Penn State Press, 2001, 1.

32 John R. Mulder, The Temple of the Mind, New York: Pegasus, 1969,64.

33 For the characteristics of the early editions of the two main variants, I refer to W.W. Greg, Marlowe's Doctor Faustus, 1604 - 1616. Parallel Texts, Oxford, Clarendon Press, 1950 and Christopher Marlowe: Doctor Faustus. A-and B texts $(1604,1616)$ eds. David Bevington and Eric Rasmussen, The Revels Plays, Manchester, Manchester University Press, 1993.

34 The case for the earlier date (c. 1588-9) of Doctor Faustus, generally now in critical favour, rests on a number of considerations. Scott McMillin and Sally-Beth MacLean note that "[t]he references to Marlowe make it evident that Doctor Faustus was on the stage well before The Troublesome Reign of King John was printed in 1591. The Queen's Men and their Plays. Cambridge: CUP, 1998, 156-57.

35 See Thomas Pettitt's account of oral transmission in "Marlowe's Texts and Oral Transmission: Towards the Zielform," Comparative Drama, ii, 30 (2005), 213-42, and also "Multiple Texts: Folkloristic Approaches to Early Modern Verbal Culture," in eds Roy Eriksen and Peter Young, Approaches to the Text: From Proto-Gospel to Post-Baroque, EMMS vol, 9, Pisa and Rome: Fabrizio Serra Editore, 2014,121-54.

36 For the misplaced comic scene, see "The Misplaced Clownage-Scene in The Tragedie of Doctor Faustus (1616) and Its Implications for the Play's Total Structure," ES, LXII (1981), 249-58. This placing is now generally accepted later by Bevington and Rasmussen (1993: 288), but who did not engage with the argument about the loco-temporal patterning of the 1616 edition.

37 See "What resting place is this: Aspects of Time and Place in Doctor Faustus (1616), RenD XVI (1985): 49-74 (6065).

38 The two comic intermezzi with Boy and Sanders can hardly be said to constitute an independent plot, but are examples of the "fond and frivolous gestures" which are worthy of comedy, according to the editor of Marlowe's Tamburlaine.

${ }^{39}$ It is symptomatic that the transformation of Kate takes place outside the city and in the topsy-turvy mood of a country festival.

${ }^{40}$ Francois Laroque, Shakespeare's Festive World. Elizabethan seasonal entertainment and the professional stage, Cambridge: CUP. 1993, 11.

${ }^{41}$ Andrea C. Castagno, The Early Commedia dell'Arte 1520-1621. The Mannerist Context, New York: Peter Lang, 1994, 159-61. The cap and poor clothes are part of the iconography of Harlequin. Commedia dell'arte companies toured in Europe between 1550-1625, peforming for the Earl of Linoln as early as in 1572.

42 Jan Harold Brunvand, "The Folk Tale Origin of The Taming of the Shrew," SQ 17(1966), 345-59.

43 C.L. Barber, Shakespeare's Festive Comedy. A Study of Dramatic Form and its Relation to Social Custom, Princeton, New Jersey: Princeton University Press, 1959, 3-15; 222-30.

44 Ann Thompson, The Taming of the Shrew, 19.

45 Unediting the Renaissance, p. 120,

${ }^{46}$ Leah Marcus, "The Shakespearean Editor as Shrew-Tamer," ELR 22.2 (1992); 177-200(183). 
47 A Pleasant Conceited Historie, Called The Taming of a Shrew, eds. Graham Holderness and Bryan Loughrey. Harvester Wheatsheaf: Hemel Wheatsheaf, 1992, p. 14.

48 Marcus, Unediting the Renaissance, 118; 119.

49 Holderness and Loughrey. "Introduction," 15-16.

50 I propose Marlowe as the author of the comedy, based on arguments of structure, and style. "The Taming of a Shrew: Composition as Induction to Authorship." NJES Vol 4.2 (December 2005, 41-61; rpt. in ed, Harold Bloom, William Shakespeare - Comedies, New Edition - Bloom's Modern Critical Views, New York: Chelsea House, 2009, 77-95; see also "Friends or Foes. Marlowe and Shakespeare as Rivals in the Republic of Letters," in ed. Hall Bjørnstad, Borrowed Feathers. Plagiarism and the Limits of Imitation in Early Modern Europe, Oslo: Unipub:, 2008, 191-200.

51 "Ars Combinatoria: Marlowe's Humanist Poetics," ed. Dominique Goy-Blanquet,

Shakespeare. Variations sur la lettre, le mètre et la mesure, Paris: Société

Shakespeare Francaise: 1996, 111-126

52 See my discussion of periodicity and borrowings from Marlowe in King John in "Working with Marlowe:

Shakespeare's Early Engagement with Marlowe's Poetics," forthcoming in Marlowe Studies: An Annual 5 (2015),

53 The Forme of Faustus Fortunes. A Study of the Tragedie of Doctor Faustus (1616), Atlantic Highlands N.J. and Oslo: Humanities Press/Solum, 1987), 193-226 and "Poetics, Stylometrics and Attribution: Periodicity in Marlowe's Doctor Faustus (1616), in eds. Roy Eriksen and Peter Young, Approaches to the Text: From Proto-Gospel to Post-Baroque, EMMS 9, Pisa and Rome: Fabrizio Serra Editore, 2014, 171-90.

54 "Poetics, Stylometrics and Attribution: Periodicity in Marlowe's Doctor Faustus (1616), in eds Roy Eriksen and Peter Young, Approaches to the Text: From Proto-Gospel to Post-Baroque, EMMS vol, 9, Pisa and Rome: Fabrizio Serra Editore, 2014, 171-90.

55 In addition to describing unifying metrical or rhythmical patterns that may mark the beginning and end of a period, Aristotle singles out three types of rhetorical repetition that perform this role: antitheton (antithesis), parisosis (equality of clauses), and paromoisis ("similarity of final syllables ... at the beginning and end of the clauses"). Paromoisis may also comprise the repetition of entire words in these positions. For the sake of clarity Aristotle provides a survey of schemes together with concrete examples in Book Three in his discussion of the structural properties the period shares with other verbal creations. Cf. The Art of Rhetoric, III.iii.6 (pp. 388; 390)

56 The Forme of Faustus Fortunes, 217.

57 With the exception of 2 Henry VI (22\%), and 3 Henry VI (23\%), Julius Caesar (21\%), other plays by Shakespeare and those of other dramatists fall short of such high percentages. Thomas Kyd's The Spanish Tragedy has less than $8 \%$ (7. 6) and Titus Andronicus less than 13 \%(12.9). See The Forme of Faustus Fortunes, p. 217.

58 For more examples, see "The Taming of a Shrew: Composition as Induction to Authorship," cited above at note.

59 The Forme of Faustus Fortunes, 217-18.

60 She neutralizes Ferando's madcap performance by matching his jesting, and he is taken by surprise: "Why so Kate this was friendly done of thee,/And kindly too: why thus must we two live,/ One mind, one heart, and one content for both. (p. 79[1159-61]). Here "thus" reveals that he understand her to have cracked the code and that they share the same attitude to the stolidity of convention and conformity.

61 These figures can be presented as follows, where the letters a, b, c refer to repeated lexical items:

1) epanalepsis (/a ... a/);

2) epanalepsis with antimetabole/chiasmus (/ab ... ba/);

3) epanados with antimetabole and /or epanalepsis (/ab ... a ...

$\mathrm{ba} /$ )

${ }^{62}$ George Taylor Coffin, "The Strange Case of Du Bartas in The Taming of a Shrew," part 2 of "Two Notes on Shakespeare," PQ 20(1941), 374.

63 Richard Hillmann, "La Création du Monde et The Taming of The Shrew: Du Bartas comme Intertexte," Renaissance and Reformation 27 (1991), 251-52.

${ }^{64}$ Ann Lake Prescott, "The Reception of Du Bartas in England," Studies in the Renaissance 15 (168), 152.

65 Holderness and Loughrey"Introduction,", 29.

66 The scene that presents the odd behaviour of Ferando and Kate towards the Duke of Cestus, is also repeated in Shakespeare. For the supposes element, see also Cecil C. Seronsy, "Supposes' as the Unifying Theme in The Taming of the Shrew," Shakespeare Quarterly 14 (1963:15-30.

67 The Traditions of English Renaissance Comedy, 201.

${ }^{68}$ As Mary Beth Rose argues in a seminal article "Sexual Love in Elizabethan Comedy," Renaissance Drama, n.s. XV(1984):1-29, changes took place in post-Reformation England towards a more integrated view of love and marriage. Still, it took a long time to unite love and marriage, and as Linda E. Boose argues in traditional English society the reality for women could be extremely harsh and brutal if they failed to comply with accepted patterns; "Scolding Brides and Bridling Scolds: Taming the Woman's Unruly member," Shakespeare Quarterly, 42: 2(1991), 179 - 213. The period around 1590 seems to have been crucial as regards love and romantic comedy, the change in 
emphasis seen in Lyly's Mother Bombie (1589), being an example of the vacillaton between different views and value systems.

${ }^{69}$ Hodgdon, "Introduction," 38.

70 Marcus agrees with Holderness and Loughrey that the play is more "progressive" than the Folio Shrew, arguing that "the editorial tradition has chosen to suppress it because 'the women are not as satisfactorily tamed as they are in The Shrew,'” Unediting the Renaissance, 108. See also Miller, "Introduction," 43. 